\title{
Bcr-Abl-mediated Raf kinase inhibitor protein suppression promotes chronic myeloid leukemia progenitor cells proliferation
} \author{
Daisuke Yokota ${ }^{2}$, Isao Hirano ${ }^{2}$, Kiyoshi Shibata ${ }^{3}$, Michio Fujie ${ }^{3}$, Shinya Fujisawa ${ }^{4}$, \\ Kazunori Ohnishi ${ }^{1,2}$

\footnotetext{
${ }^{1}$ Department of Internal Medicine III, Hamamatsu University School of Medicine, Hamamatsu, Japan;

*Corresponding Author: satonaka@hama-med.ac.jp

${ }^{2}$ Cancer Center, Hamamatsu University School of Medicine, Hamamatsu, Japan;

${ }^{3}$ Equipment Center, Hamamatsu University School of Medicine, Hamamatsu, Japan;

${ }^{4}$ Division of Hematology, Hamamatsu Medical Center, Hamamatsu, Japan.
}

Satoki Nakamura ${ }^{1^{\star \#}}$, Tomohiro Yagyu ${ }^{2 \#}$, Tomonari Takemura ${ }^{2}$, Lin Tan $^{2}$, Yasuyuki Nagata ${ }^{2}$,

Received 27 July 2011; revised 18 September 2011; accepted 30 September 2011.

\begin{abstract}
The Ras/Raf-1/MEK/ERK pathway is constitutively activated in Bcr-Abl transformed cells, and Ras activity enhances the oncogenic ability of Bcr-Abl. On the other hand, Raf kinase inhibitor protein (RKIP) inhibits activation of MEK by Raf-1 and its downstream signal transduction, resulting in blocking the MAP kinase pathway. Moreover, Raf-1 has been reported to regulate cell cycle progression. However, the mechanism by which Bcr-Abl promotes the cell cycle progression through Raf-1 is not completely understood. In the present study, we found that the expression of RKIP was suppressed in CML cells, and investigated the interaction between RKIP and Bcr-Abl in CML cells. In aldehyde dehydrogenase (ALDH) ${ }^{\mathrm{hi}} / \mathrm{CD} 34^{+}$ cells derived from CML patients, the inhibition of Bcr-Abl induced RKIP expression and reduced the phosphorylated-FOXM1 (pFOXM1) status, resulting in inhibited colony formation of $\mathrm{Bcr}^{-\mathrm{Abl}}{ }^{+}$ progenitor cells. Moreover, overexpression of RKIP significantly decreased the colony numbers, reduced the pFOXM1 status, and reduced pFOXM1 target genes such as Skp2, Cdc25B and $\mathrm{KIS}$, and induced the expression of $\mathrm{p} 27^{\mathrm{Kip} 1}$ and p21 ${ }^{c i p 1}$. Thus, Bcr-Abl represses the expression of RKIP, and continuously activates FOXM1, resulting in the proliferation of CML progenitor cells through the cell cycle modulation.
\end{abstract}

Keywords: RKIP; FOXM1; Bcr-Abl; Progenitor Cells; Cell Cycle

\footnotetext{
${ }^{\#}$ These authors contributed equally.
}

\section{INTRODUCTION}

Chronic myeloid leukemia (CML) is a hematopoietic stem cell malignancy that is characterized by the Philadelphia chromosome [1,2], a shortened chromosome 22 that is a by-product of a reciprocal chromosomal translocation between the long arms of chromosomes 9 and $22 \mathrm{t}(9 ; 22)$ (q34; q11), resulting in a chimeric Bcr-Abl oncoprotein with highly deregulated, constitutive tyrosine kinase activity $[3,4]$. The most commonly occurring from of $\mathrm{Bcr}-\mathrm{Abl}$ is a $210-\mathrm{kDa}$ protein that is a critical role in the pathogenesis of CML [5]. Bcr-Abl activates a variety of signaling pathways, including the Ras/Raf1/MEK/ERK [6], PI3K/Akt [7], JAK/STAT [8], and NF$\kappa B[9]$ signaling pathways. These signaling pathways play important role in Bcr-Abl-mediated leukemogenesis. The Ras pathway regulates multiple biological aspects including mitogenesis and differentiation $[10,11]$, and is constitutively activated in Bcr-Abl transformed cells. Moreover, inhibition of Ras activity represses the oncogenic ability of Bcr-Abl [6].

Bcr-Abl activates the Ras pathway through the adaptor protein Grb2, which associates with the guanine nucleotide exchange factor Sos and binds to the phosphorylated tyrosine residue 177 within the Bcr region of Bcr$\mathrm{Abl}$. Sos forms a platform for recruitment of Ras, resulting in the activation of Ras from GDP- to GTP-bound state $[12,13]$. The activated Ras phosphorylates Raf, and ERK is phosphorylated by MEK, which is phosphorylated and activated by the activated Raf-1 [14]. ERK then translocates into the nucleus and promotes cell proliferation through activation of various transcription factors as playing important roles in Bcr-Abl-mediated leukemogenesis [15]. On the other hand, the anti-apoptotic factor 
of the Bcl-2 family, Mcl-1, is constitutively expressed in a Ras/Raf-1/MEK-dependent manner via Ras activation in Bcr-Abl positive cells [16]. Moreover, Raf-1 has been reported to have an important role in regulation of cell cycle progression [17]. Thus, in Bcr-Abl expressing cells, Ras pathway plays an important role in both cell proliferation and survival.

Raf kinase inhibitor protein (RKIP), which is a member of the phosphatidylethanolamine binding protein 1 (PEBP1) family, is a ubiquitously expressed and constitutively conserved protein [18]. RKIP inhibits activation of MEK by Raf-1 and its downstream signal transduction, resulting in blocking the MAP kinase pathway [19, 20]. It has been reported that RKIP expression is downregulated in metastatic prostate cancers and the loss of RKIP levels promotes the metastatic potential of prostate cancer cells [21]. Moreover, RKIP has been reported to be downregulated in malignant melanoma [22], hepatocellular carcinoma [23], breast cancer [24], and colorectal cancer $[25,26]$. These data suggest RKIP might play as a tumor and/or metastasis suppressor for solid tumors. However, it has been reported that RKIP expression has no relationship with ERK phosphorylation or the clinical course of disease in patients with melanoma or breast cancer [24,27]. These different observations suggest that RKIP contributes to the regulation of not only MAPK signaling including phosphorylated ERK but also other signal pathways.

In the present study, we investigated the role of RKIP in $\mathrm{CML}$ cell lines and the $\mathrm{Bcr}-\mathrm{Abl}^{+}$hematopoietic progenitor cells derived from CML patients. We found that Bcr-Abl suppressed the expression of RKIP in CML cells, and detected changes of the cell cycle regulator proteins in CML-derived hematopoietic progenitor cells and CML cell lines. Interestingly, we also found the upregulation of $\mathrm{p} 27^{\text {Kip } 1}$ and $\mathrm{p} 21^{\text {Cip } 1}$ through FOXM1 inactivation in RKIP overexpressed-CML cells.

\section{MATERIALS AND METHODS}

\subsection{Reagents}

Imatinib mesylate (STI571) and AMN107 were kindly provided by Novartis Pharmaceuticals (Basel, Switzerland). BMS354825 was kindly provided by Bristol-Myers Squibb (New York, NY). Each compound was prepared as a $10 \mathrm{mM}$ stock solution in dimethyl sulfoxide and stored at $-20^{\circ} \mathrm{C}$. Experiments were performed with 1000 -fold dilutions of the stock solutions into reaction mixtures.

\subsection{Cells and Cell Cultures}

Human CML cell lines, K562 and Meg01, and human acute myeloblastic leukemia (AML) cell lines, U937 and
HL60, were purchased from American Type Culture Collection (Manassas, VA). We established SHG3 cells from the bone marrow of a patient with CML (chronic phase), and YRK2 cells from the bone marrow of patient with AML M5b (French-American-British (FAB) classification). These cells were cultured in RPMI 1640 containing $10 \%$ heat-inactivated fetal calf serum, $2 \mathrm{mM}$ L-glutamine, $100 \mu \mathrm{g} / \mathrm{mL}$ streptomycin, and $200 \mathrm{U} / \mathrm{mL}$ penicillin (GIBCO-BRL, Gaithersburg, MD) and maintained in a humidified $5 \% \mathrm{CO}_{2}$ atmosphere at $37^{\circ} \mathrm{C}$.

\subsection{Bone Marrow Samples}

Prior to participation in the study, patients gave informed consent according to the Declaration of Helsinki. Samples of normal bone marrow were obtained from 6 healthy volunteers. Bone marrow was also obtained from 12 patients with CML in the first chronic phase. Mononuclear cells (MNCs) were isolated from bone marrow samples by Ficoll-Hypaque density gradient centrifuga- tion. CML cells were obtained from patients before they began treatment with Abl kinase inhibitors.

\subsection{Leukemic Blast Cells Purified by ALDH Activity and CD34 Expression from Bone Marrow Derived MNCs}

For 2-color staining, MNCs were stained with antiCD34-phycoerythrin (PE) conjugated antibody (Becton Dickinson, San Jose, CA) and Aldefluor reagent (StemCo Biomedical, Durham, NC) according to the manufacturer's specifications and separated using fluorescence-activated cell sorting (FACS) (Becton Dickinson). Aldefluor substrate $(0.625 \mu \mathrm{g} / \mathrm{mL})$ was added to 2 to $7 \times$ $10^{6}$ cells $/ \mathrm{mL}$ suspended in Aldefluor assay buffer and incubated for 20 to $30 \mathrm{~min}$ at $37^{\circ} \mathrm{C}$ to allow the conversion of Aldefluor substrate to a fluorescent product that is retained within the cell because of its negative charge. The $\mathrm{ALDH}^{\mathrm{hi}}$ cells were gated, and the $\mathrm{CD} 34^{+}$and $\mathrm{CD} 34^{-}$cells in the gated $\mathrm{ALDH}^{\text {hi }}$ population were sorted on a FACS. Sorted $\mathrm{ALDH}^{\mathrm{hi}} / \mathrm{CD} 34^{+}$and $\mathrm{ALDH}^{\mathrm{hi}} / \mathrm{CD} 34^{-}$cell populations were collected in methylcellulose media (Methocut H4435; Stem Cell Technologies).

\subsection{RT-PCR and Quantitative Real-Time PCR (QRT-PCR)}

Total RNA was extracted from cells by using an RNeasy system (Qiagen, Tokyo, Japan), and $1 \mu \mathrm{g}$ RNA was reverse transcribed by using a 1st strand cDNA synthesis kit (Roche, Indianapolis, IN). PCR was performed with a DNA thermal cycler (model PTC 200; MJ Research, Watertown, MA). Oligonucleotide sequences for each primer were as follows: RKIP, sense 5'-ATGCCGGTGGACCTCAGC-3', antisense 5'-GCTGCTC- 
GTACAGTTTGGGA-3'; FOXM1, sense 5'-GGAGGAAA- TGCCACACTTAGCG-3', antisense 5'-TAGGACTTCTTGGGTCTTGGGGTG-3'; Bcr-Abl, sense 5'-CGAGCGGCTTCACTCAGA-3', antisense 5'-ACAGCATTCCGCTGACCAT-3', and GAPDH; sense 5'-GAACGGGAAGCTCACTGGCATGGC-3', antisense 5'-TGAGGTCCACCACCCTGTTGCTG-3'. PCR conditions for RKIP, FOXM1, Bcr-Abl and GAPDH were 28 cycles of denaturation at $96^{\circ} \mathrm{C}$ for $30 \mathrm{sec}$, annealing at $56^{\circ} \mathrm{C}$ for $30 \mathrm{sec}$, and extension at $72^{\circ} \mathrm{C}$ for $30 \mathrm{sec}$. PCR products were electrophoresed in a $1.5 \%$ agarose gel containing $500 \mu \mathrm{g} / \mathrm{L}$ ethidium bromide and visualized with UV light. In each experiment, RT-PCR was performed in duplicate. The quantitative real-time PCR was performed by using SYBER-Green dye on an ABI PRISM 7700 Sequence detector (Perkin-Elmer/Applied Biosystems, Foster City, CA).

\subsection{Plasmid and RNA Interference}

The full-length cDNA coding human RKIP and FOXM1 was obtained by RT-PCR from human bone marrow cDNA (BD Biosciences Clontech, Palo Alto, CA) and cloned into the eukaryotic expression vector pcDNA3.1/V5-His (Invitrogen, Carlsbad, CA). Sequences of recombinant RKIP and FOXM1 cDNAs were verified by automated sequencing.

The vectors for RNA interference (RNAi) specific to human RKIP and Bcr-Abl were constructed based on the piGENE PUR hU6 vector (iGENE Therapeutics, Tsukuba, Japan), according to the manufacturer's instructions. We used the following targeting sequences and oligonucleotides: RKIP shRNA; 5'-AAGGTGGCCTCCTTCCGTAAA-3', Bcr-Abl shRNA \#1: sense 5'-GCAGAGUUCAAAAGCCCUUdTdT-3' and antisense 5'AAGGGCUUUUGAACUCUGCdTdT-3' and Bcr-Abl shRNA \#2, sense 5'-AGCAGAGUUCAAAAGCCCUdTdT-3' and antisense 5'-AGGGCUUUUGAACUCUGCUdTdT -3'. A scrambled shRNA sequence was sense 5 -UUGUACGGCAUC AGCGUUAdTdT and antisense 5 '-UUACGUGAUGCCGUA CAAdTdT and used as a control. The vector was transfected into cells by using the Lipofectamine 2000 kit (Life Technologies, Gaithersburg, MD), according to the manufacturer's instructions. After $12 \mathrm{~h}$, the same transfection procedure was repeated, and cells were harvested 48 and $72 \mathrm{~h}$ after the initial transfection. Transfection efficiency was consistently $50 \%$ to $60 \%$, as determined by the RT-PCR measurement of RKIP, FOXM1, and Bcr-Abl mRNA.

\subsection{Lentivirus Construction and Production}

The full-length RKIP, FOXM1, and $b 3 a 2 \mathrm{Bcr}$-Abl cDNA (a kind gift from Dr. J. Y. Wang, University of California, San Diego, CA) was cloned upstream from the internal ribosomal entry site of replication-deficient, self-inacti- vating lentiviral vector, $\mathrm{pRRL}$ sin-IRES-EGFP. The RKIP, $F O X M 1$, and $B c r-A b l$ - containing vectors were termed LV-RKIP, LV-FOXM1, and LV-Bcr-Abl, respectively, and the control vector was termed LV-Con. All vector particles, pseudotyped with the vesicular stomatitis virus G glycoprotein, were produced using a three-plasmid expression system as previously described [28]. The cell-free supernatants containing virus particles, LV-RKIP, LV-FOX$M 1, L V-B c r-A b l$, and LV-Con, were separately concentrated by ultracentrifugation at $28,000 \mathrm{rpm}$ for $2 \mathrm{~h}$ at $4^{\circ} \mathrm{C}$ in an SW28 rotor. Virus vector stocks were resuspended in complete DMEM and stored at $-80^{\circ} \mathrm{C}$. The virus vector titer of pRRLsin-IRES-EGFP was derived on a fluorescence-activated cell sorter (Becton Dickinson) using transfected HeLa cells. To calculate titers, the number of target cells was multiplied by the percentage of eGFPpositive cells divided by the volume of the input virus and the titer of each concentrated lentivirus vector stock (LV-RKIP, LV-FOXM1, LV-Bcr-Abl and LV-Con), which were $3.2 \times 10^{8}, 2.4 \times 10^{8}, 3.1 \times 10^{8}$ and $4.7 \times 10^{8}$ genetransducing units per milliter, respectively.

\subsection{Immunoprecipitation and Western Blot Analysis}

For immunoprecipitation and immunoblotting, total cell lysates were prepared from the Abl kinase inhibitor treated-, DNA-transfected, and shRNA-transfected-cells. Cell lysates were incubated with the FOXM1, Rb and Abl-specific monoclonal antibody for 1 hour at $4^{\circ} \mathrm{C}$, washed Protein $\mathrm{G}$ agarose beads (sc-2002, Santa Cruz, CA) were added, and incubated overnight at $4^{\circ} \mathrm{C}$. The immunoprecipitates were washed 3 times in the lysis buffer, and proteins were eluted with the SDS sample loading buffer. Western blot analysis was performed as previously described [28] using the following antibodies: anti-RKIP goat polyclonal antibody (sc-5426, Santa Cruz), anti-FOXM1 rabbit polyclonal antibody (sc-500, Santa Cruz), anti-c-Abl mouse monoclonal antibody (sc-52990, Santa Cruz), anti-KIS rabbit polyclonal antibody (ABGENT, San Diego, CA), anti-Rb mouse monoclonal antibody (sc-74562, Santa Cruz), anti-phosphotyrosine (pTyr) mouse monoclonal antibody (sc-508, Santa Cruz), anti-p27 $7^{\text {Kip } 1}$ rabbit polyclonal antibody (sc-527, Santa Cruz), and anti-p21 ${ }^{\text {Cip } 1}$ mouse monoclonal antibody (sc469, Santa Cruz). To assure equal protein loading, similar experiments were performed with a mouse monoclonal anti-Actin antibody (C-4; ICN, Aurora, $\mathrm{OH})$ as an internal control. After being washed in Tris-buffered saline Tween, blots were incubated with horseradish peroxidase-conjugated anti-mouse, anti-rabbit, or anti-goat IgG (Amersham, Arlington Heights, IL) for $1 \mathrm{~h}$ and exposed to X-ray film at room temperature. The signal was detected by chemiluminescence with an ECL detection kit 
(Amersham).

\subsection{Cell Proliferation and Viability Assay}

To assess cell proliferation, cells $\left(1 \times 10^{4}\right)$ were seeded in 24-well plates and incubated with STI571 $(1 \mu \mathrm{M})$ at $37^{\circ} \mathrm{C}$. Cells were then transfected with RKIP DNA. After 24, 48, and 72 hours incubation, cell proliferation was measured by counting cells using a hemocytometer. To assess cell viability, the numbers of nonviable cells were determined by counting the cells that showed trypan blue uptake in a hemocytometer and reported as the percentage of untreated control cells. Each data point was performed in triplicate, and the results are reported as mean counts $\pm \mathrm{SD}$.

\subsection{Cell Cycle Analysis}

DNA content analysis was performed using propidium iodide (PI) (Sigma-Aldrich, St. Louis, MO) staining. In brief, cells were transfected with RKIP DNA. Cells were cultured in $2 \mathrm{ml}$ complete medium containing $1 \times 10^{6}$ cells at $37^{\circ} \mathrm{C}$. After 7 days incubation, the cells were washed twice with cold PBS, fixed with $70 \%$ ethanol overnight before treatment with $100 \mu \mathrm{g} / \mathrm{ml}$ RNase A, and then stained with $50 \mu \mathrm{g} / \mathrm{ml}$ PI. The relative DNA content per cell was measured by flow cytometry using an Epics Elite flow cytometer (Coulter Immunotech, Marseille, France). The percentage of cells in G1, S, and G2/M phases, was calculated using ModFit program (Becton Dickinson, San Jose, CA).

\subsection{Colony Forming Cell Assay}

$\mathrm{ALDH}^{\mathrm{hi}} / \mathrm{CD} 34^{+}$cells from CML bone marrow cells were treated the Abl kinase inhibitors, or transfected with scrambled shRNA, RKIP shRNA, Bcr-Abl shRNA \#1, RKIP DNA and FOXM1 DNA. Human clonogenic progenitor assays were performed by plating purified populations of cells at concentrations ranging from $2 \times 10^{2}$ to $7 \times$ $10^{2}\left(\mathrm{ALDH}^{\mathrm{hi}} / \mathrm{CD} 34^{+}\right)$into methylcellulose media (Methocut H4435). Colonies were enumerated under light microscopy (Zeiss, Muenchen, Germany) following incubation at $37^{\circ} \mathrm{C}, 5 \% \mathrm{CO}_{2}$, for 7 to 10 days.

\subsection{Collection of Progenitor Cells, and QRT-PCR and Western Blot Analysis in the Progenitor Cells}

After the colony forming assays, each colony was harvested by glass syringe, pooled, and washed. Immunoprecipitation and western blotting were performed using the interested antibody. An RNeasy system was used to extract total RNA from approximately $2 \times 10^{4}$ cells from each colony, and then RT-PCR and QRT-PCR were also performed using RKIP, FOXM1, Bcr-Abl, and GAPDH primers.

\subsection{Statistical Analysis}

Data are representative of at least three experiments with essentially similar results. These results are expressed as the means \pm SD from three independent experiments. The means were compared by using the Student's $t$ test. $P$ values less than 0.01 were considered statistically significant.

\section{RESULTS}

\subsection{The Abl kinase Inhibitors Induce RKIP mRNA Expression in CML Cell Lines}

RKIP mRNA were constitutively expressed in CML cell lines (K562, Meg01, and SHG3 cells) (Figure 1(a)) and AML cell lines (U937, HL60, and YRK2 cells) (Figure 1(b)). In CML cell lines, the expression of RKIP mRNA was inhibited as compared to AML cell lines. Interestingly, we found that the expression of RKIP mRNA increased in the three CML cell lines treated with Abl kinase inhibitors (STI571, AMN107, or BMS35482 5 ) for $24 \mathrm{~h}$ as compared to untreated cells. However, the Abl kinase inhibitors did not affect the RKIP mRNA expression in the AML cell lines, which did not express $B c r-A b l$ mRNA. On the other hand, in the CML cell lines transfected with Bcr-Abl shRNA \#1, the RKIP mRNA expression was significantly increased as compared to control cells. In the AML cell lines transfected with LV$B c r-A b l$, the RKIP mRNA expression was reduced as compared to control cells.

As shown in Figure 1(c), RKIP protein was also constitutively expressed in CML cell line (K562, Meg01 and SHG3 cells) and in AML cell line (HL60, U937 and YRK2 cells) (data not shown). The treatment with Abl kinase inhibitors increased the protein levels of RKIP in CML cells. Moreover, the RKIP protein level was increased in K562 and Meg01 cells transfected with Bcr$A b l$ shRNA \#1. Thus, Abl kinase inhibitors or the knockdown of Bcr-Abl protein induced RKIP protein expression. The expression of RKIP protein in CML cell lines was at a lower level compared to that in AML cell lines. On the other hand, in the AML cell lines, the Abl kinase inhibitors did not affect the levels of RKIP protein (data not shown). The Abl kinase inhibitors and knockdown of $B c r-A b l$ using shRNA also inhibited the levels of tyrosine phosphorylated Bcr-Abl (p-Bcr-Abl) in CML cells. Thus, Bcr-Abl expression regulates RKIP mRNA and protein expression. 


\subsection{Effects of RKIP Expression on CML Cell Proliferation}

RKIP expression was induced by the Abl kinase inhibitors or the knockdown of Bcr-Abl in CML cells. To examine the functional importance of RKIP expression, we transfected K562 cells with RKIP DNA, and assessed the effects of RKIP on CML cell proliferation (Figure 2(a)). When K562 cells were transfected with RKIP DNA, the cell proliferation was inhibited compared to untreated cells, and the Abl kinase inhibitor (STI571) significantly inhibited the proliferation of untreated K562 cells. The cell viability of K562 cells transfected with RKIP DNA or treated with STI571 was almost similar (Figure 2(b)). On the other hand, the expression of RKIP mRNA was significantly increased by STI571 treatment (Figure 2(c)). These results show that the Abl kinase inhibitor induces RKIP mRNA expression, and RKIP plays an important role in the inhibition of CML cell proliferation by the Abl kinase inhibitors.

Next, we examined how RKIP inhibited CML cell proliferation. The analysis of K562 cells at 5 days posttransfection with RKIP DNA indicated an increase in the percentage of cells in G1 and decrease in G2/M and S population. Moreover, no increase in the sub-G1 population of
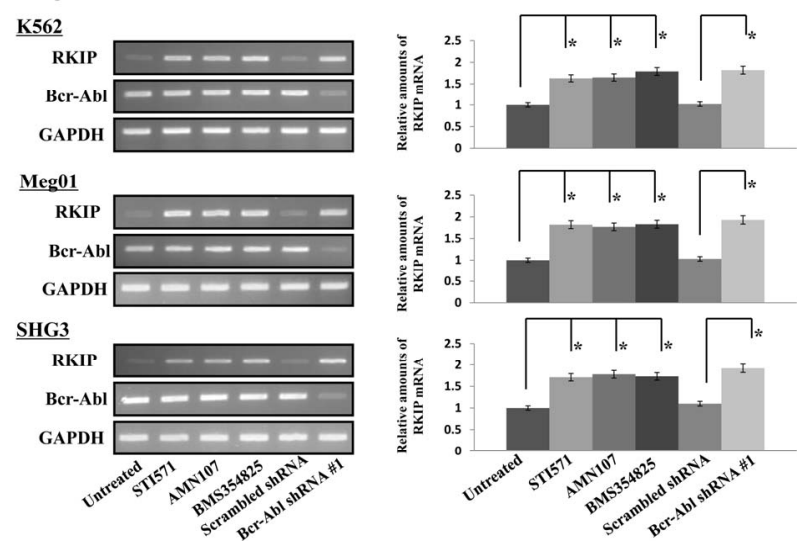

(a)
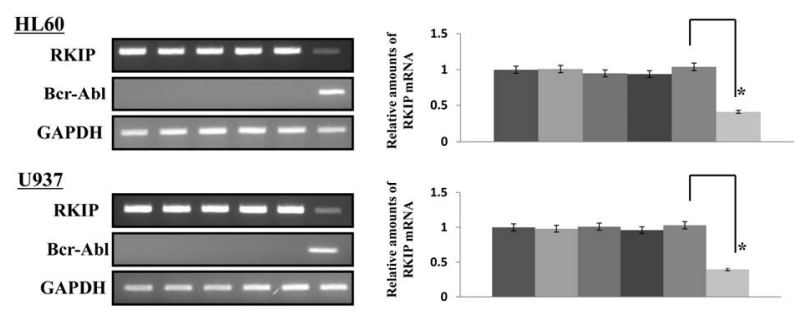

$\underline{\text { YRK2 }}$
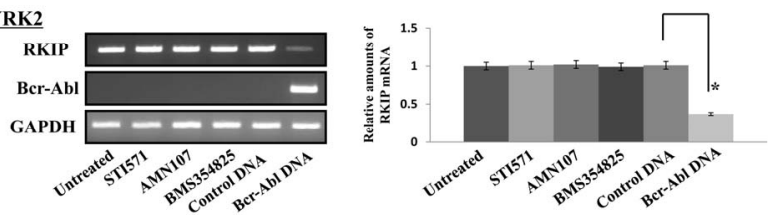

(b)
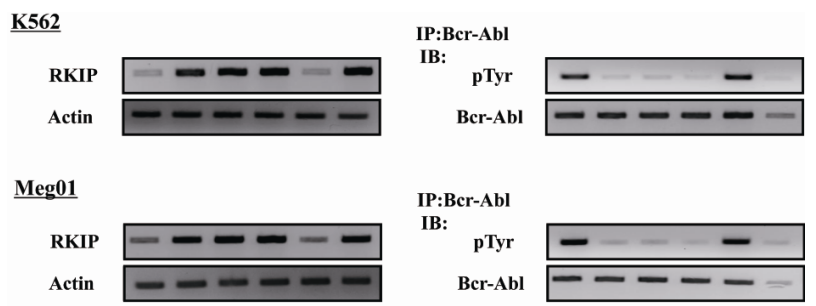

$\underline{\text { SHG3 }}$

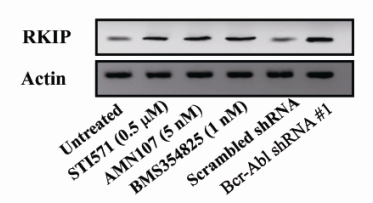

IP:Bcr-Ab]

IB:

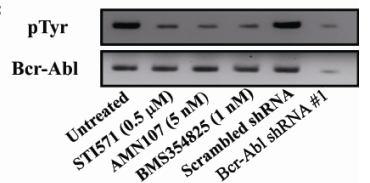

(c)

(a) \& (b) CML cell lines (K562, Meg01, and SHG3) (a) and AML cell lines (U937, HL60, and YRK2); (b) were untreated or treated with STI571 (0.5 $\mu \mathrm{M})$, ANM107 (5 nM), and BMS354825 (1 nM) for $24 \mathrm{~h}$. CML cells were harvested 3 days after transfection with control scrambled shRNA \#1 or $B c r-A b l$ shRNA \#1. AML cell lines were harvested 7 days after transfection with LV-Con or LV-Bcr-Abl. RT-PCR was performed to detect RKIP and $B c r-A b l$ mRNAs. GAPDH is shown as an internal control. RT-PCR results are representative of three independent experiments (left panels). Relative amounts of mRNAs for RKIP and Bcr-Abl were measured in CML and AML cells. The expression levels of the target mRNAs were normalized to the relative ratio of the expression of GAPDH mRNA. The results were expressed relative to untreated control set at 1. Each RT-PCR assay was performed at least three times, and the results are expressed as means $\pm \mathrm{SD}$. $* P<0.01$ compared with untreated control (right panels); (c) The effects of the Abl kinase inhibitors and Bcr-Abl shRNA \#1 on RKIP expression were assessed by western blotting. After $24 \mathrm{~h}$ treatment with the Abl kinase inhibitors or 5 days after transfection with control scrambled shRNA or Bcr-Abl shRNA \#1, total cell lysates from K562 (upper left), Meg01 (middle left) and SHG3 (bottom left) cells were prepared and analyzed by immunoblotting. Actin was used as a loading control. Total cell lysates from treated CML cells were prepared and immunoprecipitation and immunoblot analyses were performed with, anti-c-Abl and anti-pTyr antibodies (right panels).

Figure 1. RKIP mRNA protein expression in leukemia cells.

these cells was observed (Figure 2(d)). These results demonstrate that the overexpression of RKIP induces a block in G1 phase and no significant increase in apoptosis in CML cells. We previously reported that FOXM1 was aberrant expressed and promoted the cell cycle progression in leukemia cells [28]. Moreover, we also found that FOXM1 expression was aberrant expressed in CML cells, and FOXM1 knockdown inhibited CML cell proliferation (data not shown). However, in CML cells, the Abl kinase inhibitors or Bcr-Abl knockdown did not affect the expression of FOXM1 mRNA and protein. Therefore, we examined whether RKIP overexpression reduces the phosphorylation levels of FOXM1 or affects the expression of the cell cycle regulators, such as p $27^{\text {Kip } 1}$, p $21^{\text {Cip } 1}$, and KIS in CML cells. In K562 cells transfected with RKIP DNA, protein extracts were isolated posttransfected 5 days, and western blot analysis was performed to measure protein levels of these cell cycle regulators (Figure 2(e)). The FOXM1 expression 
was strongly expressed in CML cells. How ever, the overexpression of RKIP significantly reduced the pFOXM1 status and KIS expression compared to untreated cells. In contrast, the levels of $\mathrm{p} 27^{\mathrm{Kip} 1}$ and $\mathrm{p} 21^{\text {Cip } 1}$ protein were increased. The similar results were observed in other CML cell lines (Meg01 and YRK2 cells) (data not shown).

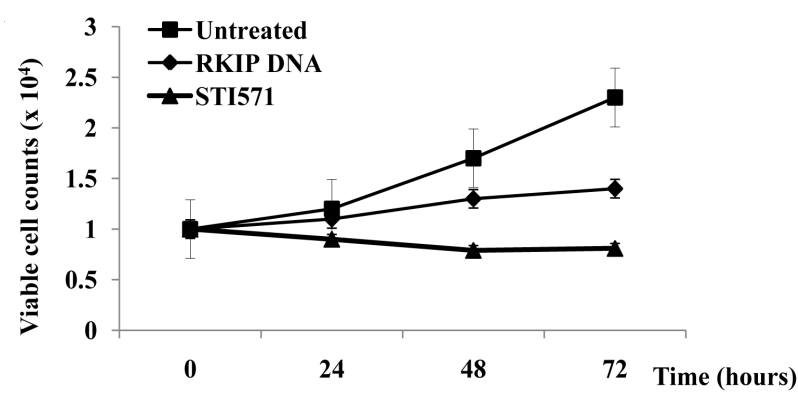

(a)

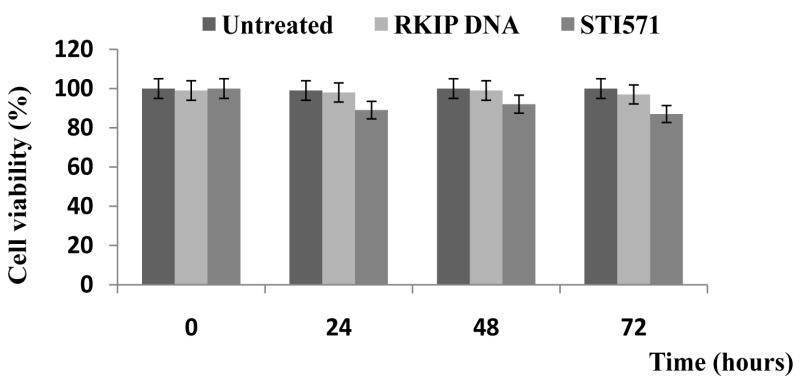

(b)

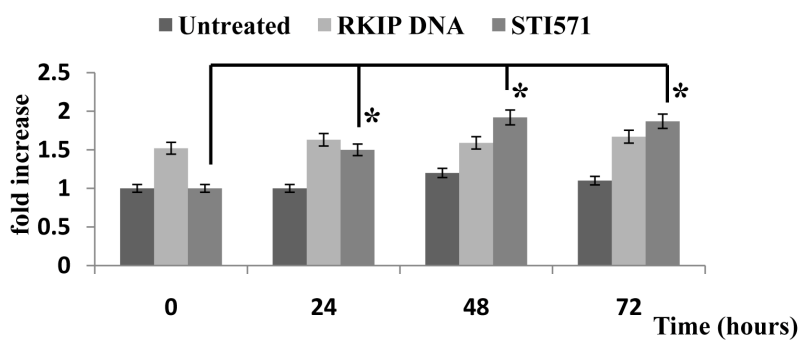

(c)

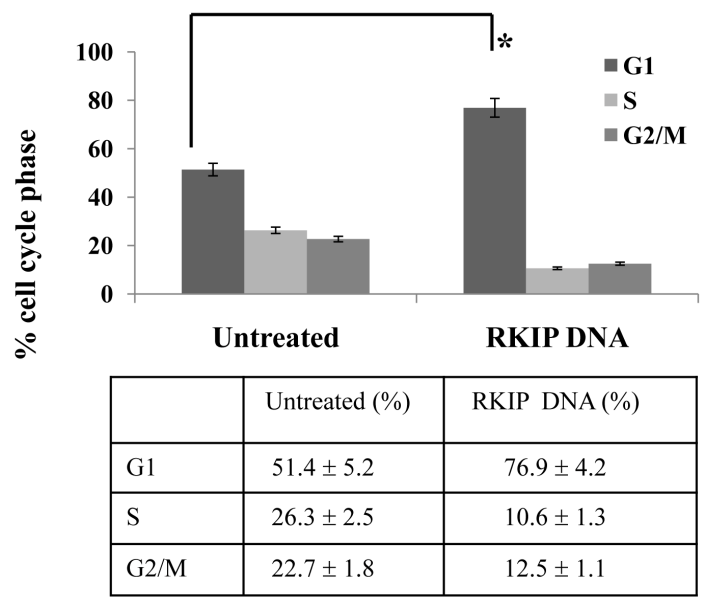

(d)

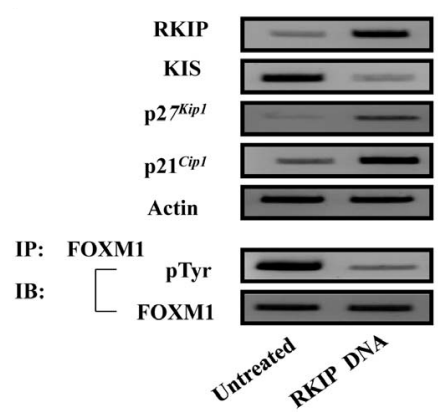

(e)

(a) and (b). K562 cells were transfected with RKIP DNA. After 5 days, the cells were treated with the STI571 $(0.5 \mu \mathrm{M})$ for 24,48 and $72 \mathrm{~h}$. Cell numbers (a) were counted and cell viability (b) was determined. The rate of K562 cell viability is expressed as the percentage of the corresponding control; (c). The RKIP DNA-transfected or untransfected K562 cells were collected at the indicated times after STI571 treatment. For the analysis of RKIP mRNA expression, quantitative RT-PCR was performed relative to the GAPDH gene. Each RT-PCR assay was performed at least three times, and the results are expressed as means \pm SD. ${ }^{*} P<0.01$ compared with untreated control cells; (d). Effects of RKIP overexpression on cell cycle in K562 cells. K562 cells were transfected with RKIP DNA. The cells were harvested posttransfected 5 days, and FACS analysis was performed to determine fraction in various cell cycle stages. Data shown as mean $\pm \mathrm{SD}$. in triplicate culture and are representative of three independent experiments. $* P<0.01$ compared with untreated control cells; (e). Evaluation of RKIP, KIS, p $27^{\text {Kip } 1}$, and $\mathrm{p} 21^{\text {Cip } 1}$ protein and FOXM1 phosphorylation levels after transfection with RKIP DNA into the cells. The cells were transfected with RKIP DNA, harvested after 5 days, and western blotting was performed by the interest antibodies for various cell cycle regulator proteins. Actin was used as a loading control.

Figure 2. Anti-proliferative effects of RKIP in K562 cells.

These results revealed that RKIP inhibited the phosphorylation of FOXM1 or KIS expression, and prevented the cell cycle progression via $27^{\text {Kip } 1}$ and p $21^{\text {Cip } 1}$ accumulation resulting in $\mathrm{G} 1$ cell cycle arrest in CML cells.

\subsection{RKIP Expression in Primary CML Progenitor Cells}

We examined the RKIP mRNA expression in clinical specimens from CML patients. Hematopoietic progenitor cells from bone marrow were obtained by flow cytometry according to ALDH activity using the substrate Aldefluor. $\mathrm{ALDH}^{\mathrm{hi}}$ hematopoietic progenitor cells, which include $\mathrm{CD}_{34}{ }^{+}, \mathrm{CD}_{133}{ }^{+}, \mathrm{c}^{-\mathrm{kit}^{+}}$or $\mathrm{Lin}^{-}$cells, were selected according to side scatter and FITC properties. CD34 ${ }^{+}$and CD $34^{-}$progenitor cells in the $\mathrm{ALDH}^{\text {hi }}$ population (ALD$\mathrm{H}^{\mathrm{hi}} / \mathrm{CD} 34^{+}$and $\mathrm{ALDH}^{\mathrm{hi}} / \mathrm{CD} 34^{-}$cells) were then sorted using FACS. We isolated $\mathrm{ALDH}^{\mathrm{hi}} / \mathrm{CD} 34^{+}$cells from bone marrow cells derived from 6 healthy volunteers and 12 CML patients, and representative data from two normal (\#3 and \#4) and two CML samples (\#10 and \#12) are shown in Figures 3(a) and (b), respectively. In bone marrow cells derived from healthy volunteers \#3 and \#4, the populations of $\mathrm{ALDH}^{\text {low }}$ cells were $96.7 \%$ and $95.4 \%$, respectively, and the populations of $\mathrm{ALDH}^{\mathrm{hi}}$ cells were 
$0.09 \%$ and $0.07 \%$, respectively. Within these $\mathrm{ALDH}^{\mathrm{hi}}$ ce$11 \mathrm{~s}$, the $\mathrm{CD} 34^{+}$cell populations were $78.1 \%$ and $80.7 \%$, and $\mathrm{CD} 34^{-}$cell populations were $20.5 \%$ and $17.4 \%$, respectively (Figure 3(a)). There were no significant differences in the population rates among 6 normal healthy volunteers. On the other hand, in bone marrow cells derived from CML patients $\# 10$ and $\# 12$, the populations of $\mathrm{ALDH}^{\text {low }}$ cells were $89.3 \%$ and $91.4 \%$, respectively, and the populations of $\mathrm{ALDH}^{\mathrm{hi}}$ cells were $4.7 \%$ and $2.6 \%$, respectively. Within these $\mathrm{ALDH}^{\mathrm{hi}}$ cells, the $\mathrm{CD}$ $34^{+}$cell populations were $82.6 \%$ and $84.1 \%$, and CD34cell population were $14.8 \%$ and $11.7 \%$, respectively (Figure 3(b)). There were no significant differences in the population rates among $12 \mathrm{CML}$ specimens. In $\mathrm{ALDH}^{\text {low }}$, $\mathrm{ALDH}^{\mathrm{hi}}, \mathrm{ALDH}^{\mathrm{hi}} / \mathrm{CD} 34^{-}$and $\mathrm{ALDH}^{\mathrm{hi}} / \mathrm{CD} 34^{+}$populations derived from CML patients, RKIP mRNA and protein were slightly expressed as compared to normal ALDH ${ }^{\text {low }}$, $\mathrm{ALDH}^{\mathrm{hi}}, \mathrm{ALDH}^{\mathrm{hi}} / \mathrm{CD} 34^{-}$and $\mathrm{ALDH}^{\mathrm{hi}} / \mathrm{CD} 34^{+}$cells (data not shown). Interestingly, in CML (\#10 and \#12)-derived $\mathrm{ALDH}^{\mathrm{hi}} / \mathrm{CD} 34^{+}$cells treated with STI571 or transfected Bcr-Abl shRNA \#1 or \#2, RKIP mRNA was strongly induced compared to untreated cells (Figure 3(c)). In normal (\#3 and \#4) ALDH ${ }^{\mathrm{hi}} / \mathrm{CD} 34^{+}$cells, the STI571 treatment did not affect the expression levels of RKIP mRNA. In contrast, the overexpression of Bcr-Abl reduced the RKIP mRNA expression. The effects of STI571 on RKIP and Bcr-Abl mRNA levels in ALDH ${ }^{\mathrm{hi}} / \mathrm{CD} 34^{+}$ cells from CML patients (\#10 and \#12) were assessed by quantitative RT-PCR. In $\mathrm{ALDH}^{\mathrm{hi}} / \mathrm{CD} 34^{+}$cells derived from all healthy volunteers $(\mathrm{n}=6)$ and all CML patients $(\mathrm{n}=12)$, there were no significant differences in the levels of RKIP mRNA induction among the other Abl kinase inhibitors (AMN107 or BMS354825). These results demonstrate that the Bcr-Abl inhibits the RKIP expression in $\mathrm{ALDH}^{\mathrm{hi}} / \mathrm{CD} 34^{+}$cells derived from CML patients.c.
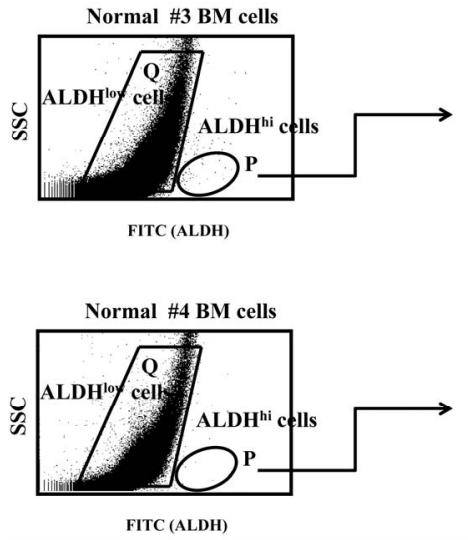

(a)
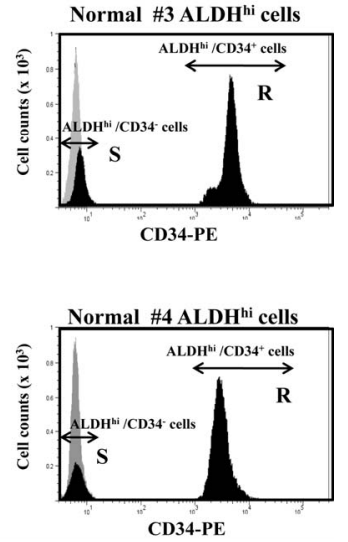

CD34-PE

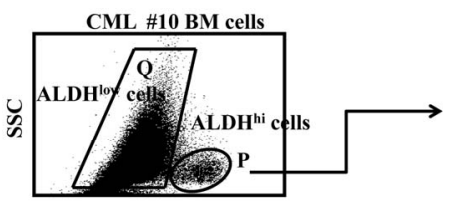

FITC (ALDH)

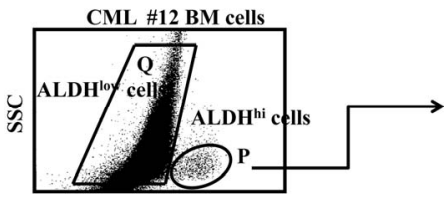

FITC (ALDH)

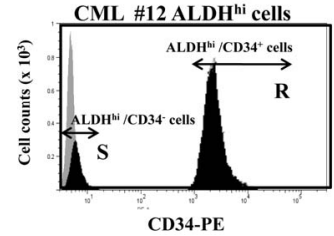

(b)

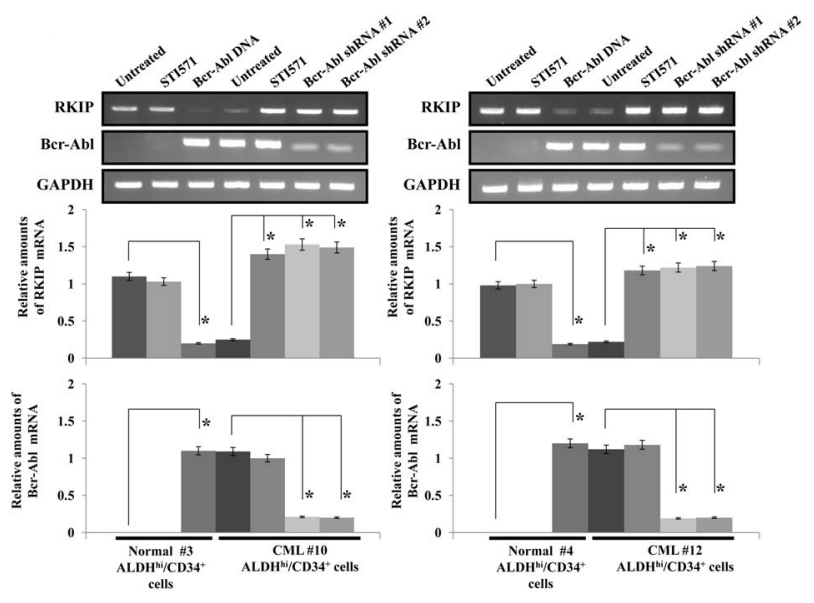

(c)

(a) \& (b). Selection of $\mathrm{ALDH}^{\mathrm{hi}} / \mathrm{CD} 34^{+}$hematopoietic progenitor cells from the bone marrow of two healthy volunteer (\#3 and \#4) (a) and from two CML patient (\#10 and \#12) (b). Region $\mathrm{P}$ and $\mathrm{Q}$ denote populations of $\mathrm{ALDH}^{\text {hi }}$ and $\mathrm{ALDH}^{\text {low }}$ cells, respectively (left panels). Region R and S denote populations CD34 $4^{+}$and $\mathrm{CD} 34^{-}$cells in the $\mathrm{ALDH}^{\mathrm{hi}}$ population (Region $\mathrm{P})$, respectively. Negative control (light grey region) and CD34-PE staining (dark grey region) (right panels); (c). The expression of RKIP and $B c r-A b l$ mRNA in sorted $\mathrm{ALDH}^{\mathrm{hi}} / \mathrm{CD} 34^{+}$cells from two healthy volunteers (\#3 and \#4) and from two CML patients (\#10 and \#12) were analyzed after treatment with STI571 $(0.5 \mu \mathrm{M})$. After 3 days STI571 treatment or 5 days after transfection with Bcr-Abl shRNA \#1 and \#2, the cells were harvested. The effects of STI571 treatment or Bcr-Abl knockdown on RKIP and $B c r-A b l$ mRNA levels in ALDH ${ }^{\text {hi }} / \mathrm{CD} 34^{+}$cells were assessed by QRT-PCR. Representative data are shown (upper panels). The levels of target mRNAs were normalized to the relative ratio of the expression of GAPDH mRNA (middle and bottom panels). The results are expressed relative to the untreated control, which is set at a value of 1. Each RT-PCR assay was performed at least three times and the results are expressed as means $\pm \mathrm{SD}$. ${ }^{*} P$ $<0.01$ compared with untreated control cells.

Figure 3. RKIP expression in hematopoietic progenitor $\mathrm{ALDH}^{\text {hij }}$ $\mathrm{CD} 34^{+}$cells derived from CML patients.

\subsection{Induction of RKIP Expression Inhibited the Colony Formation in CML Derived ALDH $^{\text {hi }} /$ CD $34^{+}$Progenitor Cells}

We examined the effect of Abl kinase inhibitors or knockdown of Bcr-Abl on the colony formation of ALD$\mathrm{H}^{\text {hi }} / \mathrm{CD} 34^{+}$hematopoietic progenitor cells from pretreat- 
ment a CML patient \#10 (Figure 4). The $\mathrm{ALDH}^{\mathrm{hi}} / \mathrm{CD} 34^{+}$ cells, which were untransfected or transfected with $\mathrm{BCr}$ Abl shRNA \#1, were treated with Abl kinase inhibitors for 7 to 10 days, and then the colony numbers were counted. When untreated, the mean colony number was 116 (range, 98 - 127). When treated with STI571, AMN107, BMS354825, or Bcr-Abl shRNA \#1 transfection, the mean colony numbers were 11 (6 - 17), 8 (1 - 14), 5 (2 - 11), 4 $(0-7)$, respectively (Figure 4(a)). The colony numbers were remarkably reduced when the cells were cultured with STI571, AMN107, or BMS354825 and transfected with $B c r-A b l$ shRNA \#1. The difference between the effects of Abl kinase inhibitors and the knockdown of Bcr$\mathrm{Abl}$ was not significant in CML-derived $\mathrm{ALDH}^{\text {hi }} / \mathrm{CD} 34^{+}$ cells. Moreover, in CML-derived $\mathrm{ALDH}^{\mathrm{hi}} / \mathrm{CD}-34^{+}$cells treated with the $\mathrm{Abl}$ kinase inhibitors or transfected with $B c r-A b l$ shRNA \#1, the RKIP protein expression was increased and the phosphorylation levels of FOXM1 were decreased compared to untreated or untransfected cells. On the other hand, the Abl kinase inhibitors or Bcr-Abl knockdown did not affect the expression of FOXM1 mRNA and protein. To assess the function of RKIP expression on colony formation of the CML derived AL$\mathrm{DH}^{\mathrm{hi}} / \mathrm{CD} 34^{+}$cells, we investigated whether the overexpression or suppression of RKIP expression affect the activity of colony formation. As shown in Figures 4(b) and 4(c), the overexpression of RKIP significantly decreased the colony numbers, and reduced the phosphorylation levels of FOXM1. On the other hand, the overexpression did not affect the expression of FOXM1 mRNA and protein. The reduction of RKIP expression slightly increased the colony numbers by STI571 treatment compared to when not transfected with RKIP shRNA \#1. Moreover, in the RKIP shRNA-transfected $\mathrm{ALDH}^{\mathrm{hi}} / \mathrm{CD} 34^{+}$ cells, the induction of RKIP expression by STI571 was weakened. There were no significant differences in the levels of RKIP mRNA induction among CML specimens. These results demonstrate that the inhibition for Bcr-Abl expression induced the RKIP expression and reduced the phosphorylation levels of FOXM1, and the overexpression of RKIP inhibited the colony formation of ALD$\mathrm{H}^{\text {hi }} / \mathrm{CD} 34^{+}$cells from CML specimens through the reduction of the pFOXM1 status.

\subsection{Induction of RKIP Expression Reduced the Phosphorylation Levels of FOXM1 in CML-Derived ALDH ${ }^{\text {hi }} /$ CD34 ${ }^{+}$ Progenitor Cells}

Finally, we examined whether overexpression of RKIP reduced the phosphorylation levels of FOXM1 in CML (\#10)-derived $\mathrm{ALDH}^{\mathrm{hi}} / \mathrm{CD} 34^{+}$cells (Figure 5(a)). When the CML-derived $\mathrm{ALDH}^{\mathrm{hi}} / \mathrm{CD} 34^{+}$cells were treated with STI 571 or transfected with RKIP DNA, RKIP expres- sion was increased, and the phosphorylation levels of FOXM1 were decreased. Moreover, the phosphorylation levels of $\mathrm{Rb}$ were also decreased. We found that the induction of RKIP expression decreased phosphorylated FOXM1 and Rb levels in CML derived $\mathrm{ALDH}^{\mathrm{hi}} / \mathrm{CD} 34^{+}$ cells. These results show that activated $\mathrm{Rb}$ inhibited the phosphorylation of FOXM1. Next, we examined whether the FOXM1 overexpression rescued the effects of cell cycle genes essential for G1-S progression, including Skp2, Cdc25B, KIS, p2 $7^{\text {Kip } 1}$, and $\mathrm{p} 21^{\text {Cip } 1}$ by treatment with STI571 in CML derived $\mathrm{ALDH}^{\mathrm{hi}} / \mathrm{CD} 34^{+}$cells (Figure 5(b)). When the CML derived $\mathrm{ALDH}^{\mathrm{hi}} / \mathrm{CD} 34^{+}$ cells were treated with STI 571 or transfected with RKIP DNA, the phosphorylation levels of FOXM1 and the expression of Skp2, Cdc25B and KIS protein were decreased, and the expression of CDKIs (p27 $7^{\text {Kip } 1}$ and p2 $21^{\text {Cip } 1}$ ) protein was increased. On the other hand, in FOXM1 DNA transfected-ALDH ${ }^{\text {hi }} / \mathrm{CD} 34^{+}$cells, the reduction of Skp2, Cdc25B and KIS expression by STI571 treatment was inhibited, and the induction of $\mathrm{p} 27^{\text {Kip } 1}$ and $\mathrm{p} 21^{\text {Cip } 1}$ expression by STI571 treatment was inhibited. These results indicate that RKIP promotes cell cycle progresssion through the reduction of the pFOXM1 status, and has an important role in $\mathrm{ALDH}^{\mathrm{hi}} / \mathrm{CD} 34^{+} \mathrm{CML}$ cell proliferation.

\section{DISCUSSION}

We investigated the role of RKIP expression on the cell growth inhibition of CML cells and CML-derived progenitor cells. In this study, we demonstrated that Bcr-Abl inhibited the expression of RKIP and promoted the CML cell proliferation through the FOXM1 activation.

The Ras/Raf-1/MEK/ERK signaling pathway is known to be essential for cellular proliferation, differentiation, apoptosis, survival and migration [29,30]. The deregulation of them leads to various diseases including malignancies [20,31] and developmental disorders [32]. However, the regulation of Ras/Raf-1/MEK/ERK pathway is very complex and not clearly understood. It has been reported that RKIP binds to Raf-1 and disrupt downstream of MAP kinase pathway [19], and the overexpression of RKIP can act as a competitive inhibitor MEK [20]. Moreover, RKIP expression has been shown to downregulated in metastatic prostate cancers and the loss RKIP levels was suggested to promotes the metastatic potential of prostate cancer cells [21], and it has been shown to be a decrease of RKIP expression in malignant melanoma and breast cancer cells [24,33], and the absence of RKIP expression in melanoma metastases [22].

In cell cycle effects, ERK/MAPK-independent functions of Raf kinases have been reported. Raf-1 activates the Cdk25 phosphatase, which results in CDK activation [17]. 


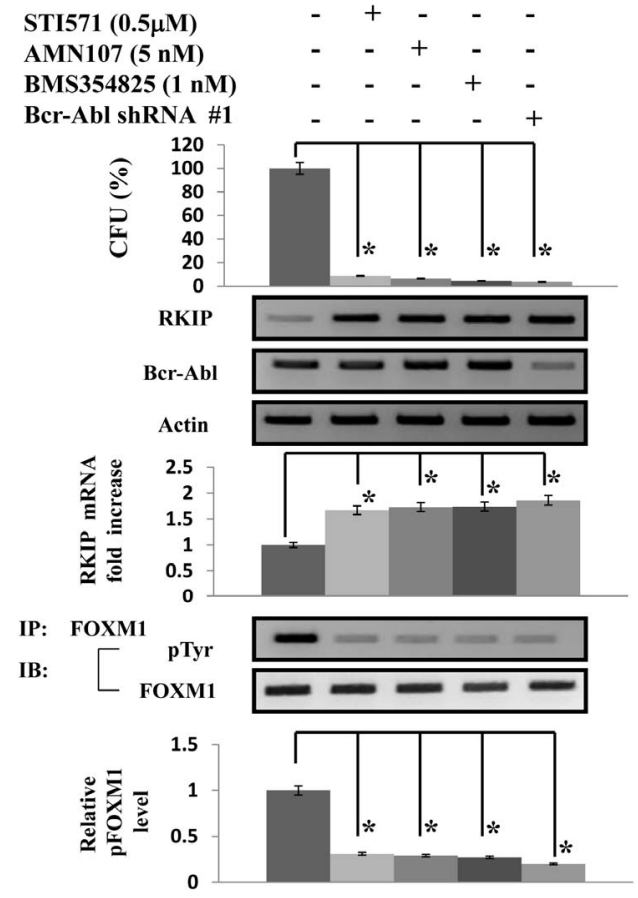

(a)
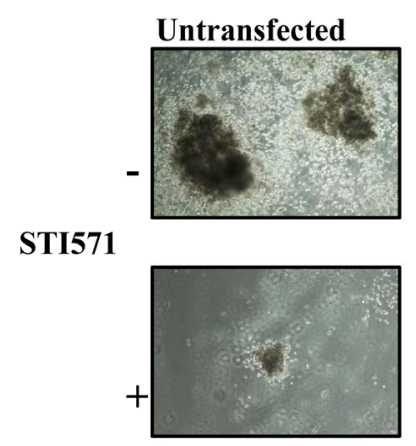

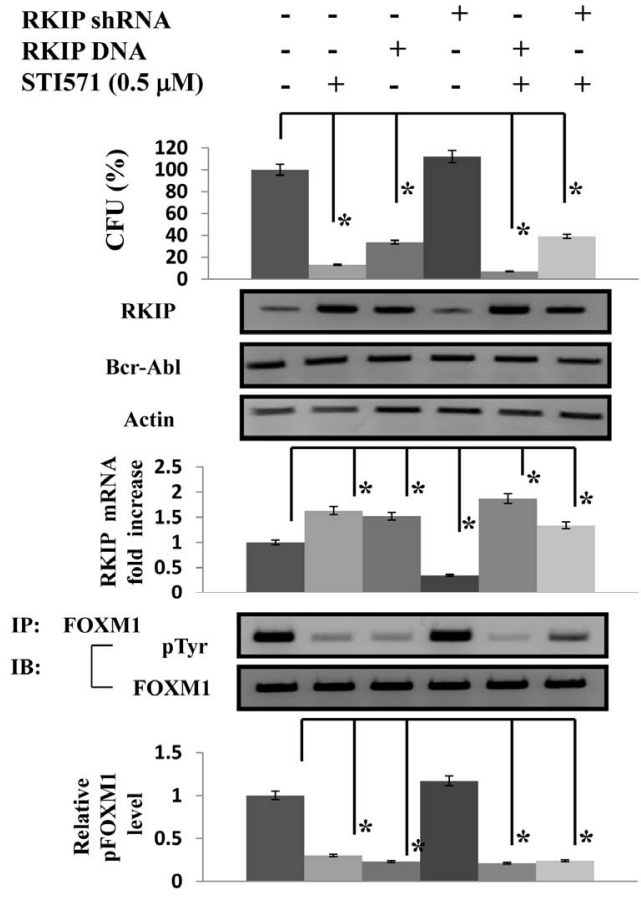

(b)

RKIP shRNA
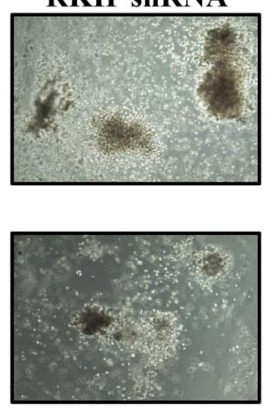

(c)
RKIP DNA
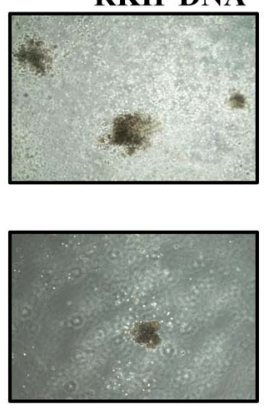

(a) The purified $\mathrm{ALDH}^{\mathrm{hi}} / \mathrm{CD} 34^{+}$cells $\left(3 \times 10^{2}\right.$ to $5 \times 10^{2}$ cells/plate) from a CML patient (\#10) were isolated and cultured in semisolid methylcellulose media (Methocult; H4435). The $\mathrm{ALDH}^{\mathrm{hi}} / \mathrm{CD} 34^{+}$cells, which were untransfected or transfected with $B c r-A b l$ shRNA \#1, were treated with the Abl kinase inhibitors, and were enumerated after 7 to 10 days of in vitro culture. The rate of the progenitor cells was evaluated as the percentage of the corresponding control (top panel). To detect RKIP and Bcr-Abl protein, western blot was performed. Actinis shown as a loading control. Representative data are shown (middle panels). For the analysis of RKIP mRNA expression, QRT-PCR was performed relative to the GAPDH gene (middle panels). The densitometric analysis of pFOXM1 levels in $\mathrm{ALDH}^{\mathrm{hi}} / \mathrm{CD} 34^{+}$cells from the $\mathrm{CML}$ patient (\#10). Immunoprecipitation and western blot analysis were performed by using anti-pTyr antibodies and anti-FOXM1 antibodies. Results are representative of three independent experiments (bottom panels); (b) $\mathrm{ALDH}^{\text {hi }} / \mathrm{CD} 34^{+}$cells were transfected with RKIP DNA or RKIP shRNA and then treated with STI571 $(0.5 \mu \mathrm{M})$ for 7 to 10 days. The numbers of colony were counted. The rate of the progenitor cells was evaluated as a percentage of the corresponding control. To detect RKIP and Bcr-Abl protein, western blot was performed. Actin is shown as a loading control. Representative data are shown (middle panels). For the analysis of RKIP mRNA expression, QRT-PCR was performed relative to the GAPDH gene (middle panels). The densitometric analysis of $\mathrm{pFOXM1}$ levels in $\mathrm{ALDH}^{\mathrm{hi}} / \mathrm{CD} 34^{+}$cells from the CML patient (\#10). Immunoprecipitation and western blot analysis were performed by using anti-pTyr antibodies and anti-FOXM1 antibodies. Results are representative of three independent experiments (bottom panels). Data are shown as the mean \pm SD in triplicate culture and are representative of three independent experiments. Data are shown as the mean \pm SD in triplicate culture and are representative of three independent experiments. ${ }^{*} P<0.01$ compared with untreated control cells; (c) The cells transfected with RKIP DNA or shRNA were viewed using phase-contrast microscopy after 14 days culture with or without STI571 $(0.5 \mu \mathrm{M})$. Original magnification $\times 4$.

Figure 4. RKIP regulates FOXM1 activation on $\mathrm{ALDH}^{\mathrm{hi}} / \mathrm{CD} 34^{+}$hematopoietic progenitor cells derived from CML patients. 


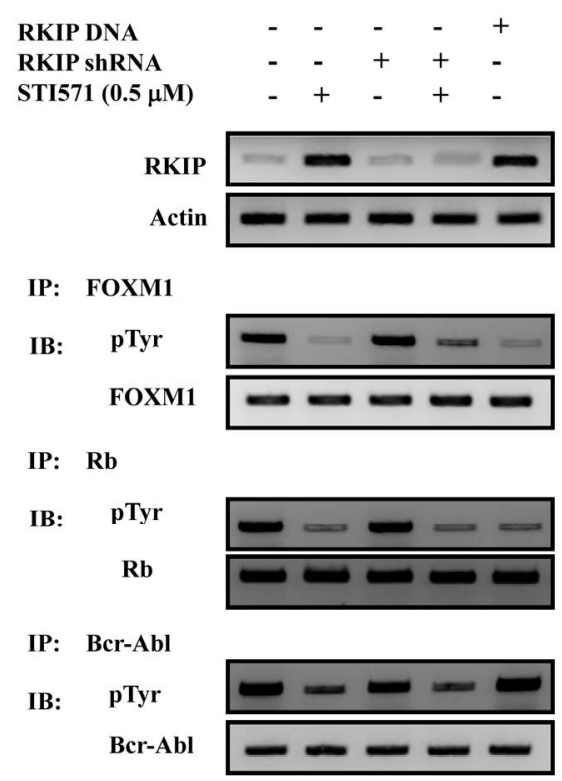

(a)

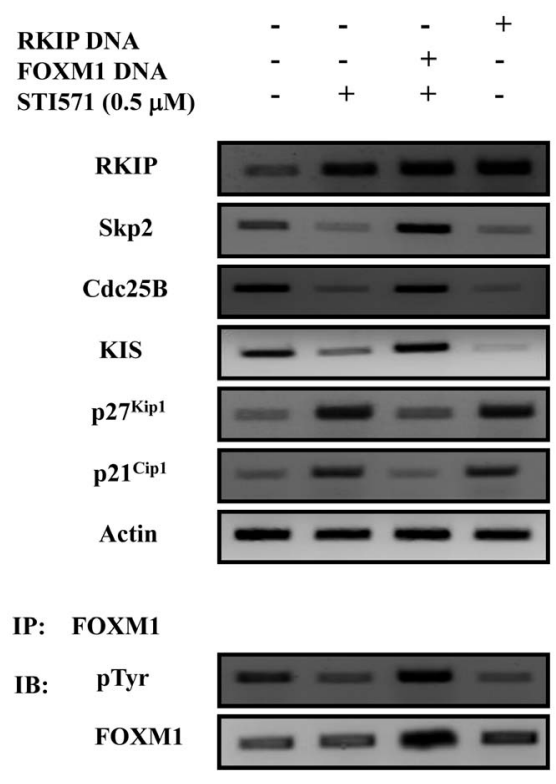

(b)

(a) Expression of RKIP, phosphorylated FOXM1, phosphorylated Rb and phosphorylated Bcr-Abl protein in ALD$\mathrm{H}^{\text {hi }} / \mathrm{CD} 34^{+}$cells isolated from two a CML patient (\#10) was analyzed after 40 minutes treatment with STI571 $(0.5 \mu \mathrm{M})$ using immunoprecipitation and immunoblot analyses. Representative data are shown. Actin was used as a loading control; (b) Expression of RKIP, Skp2, Cdc25B, KIS, p2 $7^{\text {Kip1 }}$, and p $21^{\text {Cip } 1}$ protein and pFOXM1 in purified ALDH ${ }^{\text {hi }} / \mathrm{CD}^{2} 4^{+}$ cells from one CML patient (\#10). $\mathrm{ALDH}^{\mathrm{hi}} / \mathrm{CD} 34^{+}$cells $\left(3 \times 10^{2}\right.$ to $5 \times 10^{2}$ cells/plate) were untransfected or were transfected with RKIP DNA and FOXM1 DNA, plated in semisolid methylcellulose media and were then treated with STI571 $(0.5 \mu \mathrm{M})$ for 24 hours using immunoblot analyses. Representative data are shown. Immunopretipitation and western blot analysis was performed by using anti-RKIP, anti-Skp2, anti-Cdc25B, anti-KIS, anti-p27 ${ }^{\text {Kip } 1}$, anti-p21 ${ }^{\text {Cip } 1}$, anti-pTyr antibodies and anti-FOXM1 antibodies. The levels of Actin served as the loading control.

Figure 5. RKIP reduces the phosphorylation of FOXM1 and modulates the cell cycle associated proteins.

The activated CDK4/6 and CDK2 inactivated $\mathrm{pRb}$ with Cyclin D and Cyclin E, respectively, which results in cell cycle progression from G1/S transition until the entry into mitosis. In the present study, we found that treatment with Abl kinase inhibitors or reduction of BcrAbl induced the expression of RKIP, reduced the phosphorylated FOXM1 in CML cells and $\mathrm{Bcr}-\mathrm{Abl}^{+}$progenitor cells from CML patients. Moreover, the overexpre-

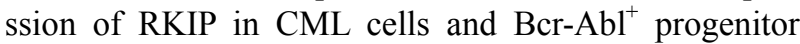
cells inhibited their proliferation through the reduction of the pFOXM1 status. These results demonstrate that RKIP is suppressed by Bcr-Abl and the induction of RKIP inhibits the CML progenitor cell proliferation.

In this study, we found at the first time that RKIP inhibited the phosphorylation of FOXM1, the central regulator of the cell cycle, resulting in G1 cell cycle arrest via $\mathrm{p} 27^{\text {Kip } 1}$ and $\mathrm{p} 21^{\text {Cip } 1}$ accumulation in CML progenitor cells. Expression and phosphorylation of FOXM1 is induced during the G1 phase of the cell cycle, its expression continues during $\mathrm{S}$ phase and mitosis [34]. FOXM1 activity is subjected to different levels of regulation [35]. Upon mitogenic stimulation, Cyclin D/Cdk4, 6 and Cyclin E/Cdk2 inactivate phosphorylated-Rb (pRb), allowing the cells to progress to S-phase, but also relieving inhibition of FOXM1 by pRb. Furthermore, FOXM1 has been shown to regulate transcription of cell cycle genes essential for G1-S and G2-M progression and chromosome stability and segregation, including Nek2, KIF20A, CENP-A, CENP-F, CDc25A, CDc25B, p27 $7^{\text {Kip } 1}$, KIS, Cyclin B, and Cyclin D [35-39]. FOXM1 has been also reported to contribute to oncogenesis in basal cell carcinomas, hepatocellular carcinomas, and primary breast cancer [40,41]. Moreover, we have been reported that in acute leukemia cell lines, the expression of FOXM1 mRNA was significantly higher than normal progenitor cells [28]. The reduction of FOXM1 expression increased protein expression of $\mathrm{p} 21^{\text {Cip } 1}$ and $\mathrm{p} 27^{\text {Kip } 1}$. In the clinical samples (127AML (M1; 21, M2; 56, M4; 32, M5; 18)), FOXM1 mRNA was overexpressed in all AML specimens $(127 / 127 ; 100 \%)$. The relative folds of FOXM1 gene expression were for AML: $2.14 \pm 0.31$ (M1), $2.26 \pm 0.47$ (M2), $1.65 \pm 0.42$ (M4), and $1.92 \pm 0.38$ (M5). In $\mathrm{ALDH}^{\mathrm{hi}} / \mathrm{CD} 34^{+}$progenitor cells derived from AML patients, the colony numbers were remarkably increased by FOXM1 overexpression. FOXM1 is an essential transcription factor for development of acute leukemia cells, and regulate the growth of 
$\mathrm{ALDH}^{\mathrm{hi}} / \mathrm{CD} 34^{+}$progenitor cells derived from AML patients. In this study, we also showed that FOXM1 expression in CML cells was increased compared to normal $\mathrm{ALDH}^{\mathrm{hi}} / \mathrm{CD} 34^{+}$cells. However, the Abl kinase inhibitors or Bcr-Abl knockdown did not affect the expression of FOXM1 mRNA and protein. On the other hand, the overexpression of RKIP or Bcr-Abl knockdown reduced the pFOXM1 status and KIS expression, and induced $\mathrm{p} 27^{\text {Kip } 1}$ and $\mathrm{p} 21^{\text {Cip } 1}$ expression resulting in inhibition of CML cells. These results demonstrate that FOXM1 may be one of target proteins for RKIP.

The $\mathrm{ALDH}^{\mathrm{hi}} / \mathrm{CD} 34^{+}$progenitor cells derived from CML patients were significantly reduced when they were treated with STI571, AMN107, and BMS354825 or transfected with $B c r-A b l$ shRNA \#1. Moreover, the relative ex- pression of RKIP mRNA was increased and the pFOX- M1 status was decreased in the progenitor cells treated with the Abl kinase inhibitors or transfected with Bcr-Abl shRNA \#1. In ALDH ${ }^{\mathrm{hi}} / \mathrm{CD} 34^{+}$progenitor cells transfected with RKIP DNA, the colony forming activity was inhibited, and the combination with the Abl kinase inhibitor showed more strong effects. In contrast, in $\mathrm{ALDH}^{\text {hi }} / \mathrm{CD} 4^{+}$progenitor cells transfected with $R K I P$ shRNA, the inhibition effects of colony formation activity by the Abl kinase inhibitors were weakened. These results indicate that the expression of RKIP induced by the Abl kinase reduce the pFOXM1 status and colony-forming cells derived from CML progenitor cells. Moreover, the RKIP overexpression decreased the phosphorylation levels of FOXM1 and $\mathrm{Rb}$ proteins, promoted the cell cycle progression via reduction Skp2, Cdc25B, and KIS proteins expression and induction of $\mathrm{p} 27^{K i p 1}$ and $\mathrm{p} 21^{\text {Cip } 1}$ expression in CML-derived ALD$\mathrm{H}^{\text {hi }} / \mathrm{CD} 34^{+}$progenitor cells. These findings indicate that Bcr-Abl inhibited the expression of RKIP, and reduced the phosphorylated FOXM1, resulting in the promotion of $\mathrm{Bcr}-\mathrm{Abl}^{+}$progenitor cell proliferation.

This study shows for the first time that Bcr-Abl represses the expression of RKIP and that the Abl kinase inhibitors induced RKIP expression. Moreover, RKIP reduces the pFOXM1 status. These induced RKIP plays an important role in cell growth inhibition in CML progenitor cells in vitro.

\section{CONFLICT OF INTEREST}

None of the authors have competing financial interests in relation to the work described in this article.

\section{ACKNOWLEDGEMENTS}

This work was supported by a grant-in-aid for scientific research (\#17590987) from the Ministry of Education, Culture, Sports, Science, and Technology of Japan.

\section{REFERENCES}

[1] Kurzrock, R., Gutterman, J.U. and Talpaz, M. (1988) The molecular genetics of Philadelphia chromosome-positive leukemias. New England Journal of Medicine, 319, 990998. doi:10.1056/NEJM198810133191506

[2] Rudkin, C.T., Nowell, P.C. and Hungerford, D.A. (1964) DNA contents of chromosome ph1 and chromosome 21 in human cronic granulocytic leukemia. Science, 144, 1229-1231. doi:10.1126/science.144.3623.1229

[3] Shtivelman, E., Lifshitz, B., Gale, R.P. and Ganaani, E. (1985) Fused transcript of abl and bcr genes in chronic myelogenous leukaemia. Nature, 315, 550-554. doi: $10.1038 / 315550 \mathrm{a} 0$

[4] Lugo, T.G., Pendergast, A.M., Muller, A.J. and Witte, O.N. (1990) Tyrosine kinase activity and transformation potency of bcr-abl oncogene products. Science, 247, 1079-1082. doi:10.1126/science. 2408149

[5] Daley, G.Q., Van, Etten, R.A. and Baltimore, D. (1990) Induction of chronic myelogenous leukemia in mice by the P210bcr/abl gene of the Philadelphia chromosome. Science, 247, 824-830. doi:10.1126/science.2406902

[6] Sawyers, C.L., McLaughlin, J. and Witte, O.N. (1995) Genetic requirement for Ras in the transformation of fibroblasts and hematopoietic cells by the Bcr-Abl oncogene. Journal of Experimental Medicine, 181, 307313.doi:10.1084/jem.181.1.307

[7] Skorski, T., Bellacosa, A., Nieborowska-Skorska, M., Majewski, M., Martinez, R., Choi, J.K., Trotta, R., Wlodarski, P., Perrotti, D., Chan, T.O., Wasik, M.A., Tsichlis, P.N. and Calabretta, B. (1997) Transformation of hematopoietic cells by $\mathrm{BCR} / \mathrm{ABL}$ requires activation of a PI-3k/Akt-dependent pathway. EMBO Journal, 16, 61516161.doi:10.1093/emboj/16.20.6151

[8] Carlesso, N., Frank, D.A. and Griffin, J.D. (1996) Tyrosyl phosphorylation and DNA binding activity of signal transducers and activators of transcription (STAT) proteins in hematopoietic cell lines transformed by Bcr/Abl. Journal of Experimental Medicine, 183, 811-820. doi:10.1084/jem.183.3.811

[9] Reuther, J.Y., Reuther, G.W., Cortez, D., Pendergast, A.M. and Baldwin Jr., A.S. (1998) A requirement for NFkappa B activation in Bcr-Abl-mediated transformation. Genes and Development, 12, 968-981. doi:10.1101/gad.12.7.968

[10] Nottage, M. and Siu, L.L. (2002) Rationale for Ras and raf-kinase as a target for cancer therapeutics. Current Pharmaceutical Design, 8, 2231-2241. doi:10.2174/1381612023393107

[11] O’Neill, E. and Kolch, W. (2004) Conferring specificity on the ubiquitous Raf/MEK signalling pathway. British Journal of Cancer, 90, 283-288. doi:10.1038/sj.bjc. 6601488

[12] Ren, R. (2005) Mechanisms of BCR-ABL in the pathogenesis of chronic myelogenous leukaemia. Nature Reviews Cancer, 5, 172-183.doi:10.1038/nrc1567

[13] Pendergast, A.M., Quilliam, L.A., Cripe, L.D., Bassing, C.H., Dai, Z., Li, N., Batzer, A., Rabun, K.M., Der, C.J. and Schlessinger, J. (1993) BCR-ABL-induced oncogenesis is mediated by direct interaction with the $\mathrm{SH} 2$ domain of the GRB-2 adaptor protein. Cell, 75, 175-185.

[14] Chang, F., Steelman, L.S., Lee, J.T., Shelton, J.G., Navo- 
lanic, P.M., Blalock, W.L., Franklin, R.A. and McCubrey, J.A. (2003) Signal transduction mediated by the Ras/Raf/ MEK/ERK pathway from cytokine receptors to transcription factors: Potential targeting for therapeutic intervention. Leukemia, 17, 1263-1293. doi:10.1038/sj.leu.2402945

[15] Sattler, M., Mohi, M.G., Pride, Y.B., Quinnan, L.R., Malouf, N.A., Podar, K., Gesbert, F., Iwasaki, H., Li, S., Van Etten, R.A., Gu, H., Griffin, J.D. and Neel, B.G. (2002) Critical role for Gab2 in transformation by BCR/ABL. Cancer Cell, 1, 479-492. doi:10.1016/S1535-6108(02)00074-0

[16] Aichberger, K.J., Mayerhofer, M., Krauth, M.T., Skvara, H., Florian, S., Sonneck, K., Akgul, C., Derdak, S., Pickl, W. F., Wacheck, V., Selzer, E., Monia, B.P., Moriggl, R., Valent, P. and Sillaber, C. (2005) Identification of mcl-1 as a BCR/ABL-dependent target in chronic myeloid leukemia (CML): Evidence for cooperative antileukemic effects of imatinib and mcl-1 antisense oligonucleotides. Blood, 105, 3303-3311. doi:10.1182/blood-2004-02-0749

[17] Hindley, A. and Kolch, W. (2002) Extracellular signal regulated kinase (ERK)/mitogen activated protein kinase (MAPK)-independent functions of Raf kinases. Journal of Cell Science, 115, 1575-1581.

[18] Serre, L., Pereira, de Jesus, K., Zelwer, C., Bureaud, N., Schoentgen, F. and Benedetti, H. (2001) Crystal structures of YBHB and YBCL from Escherichia coli, two bacterial homologues to a Raf kinase inhibitor protein. Journal of Molecular Biology, 310, 617-634. doi:10.1006/jmbi.2001.4784

[19] Yeung, K., Seitz, T., Li, S., Janosch, P., McFerran, B., Kaiser, C., Fee, F., Katsanakis, K.D., Rose, D.W., Mischak, H., Sedivy, J.M. and Kolch, W. (1999) Suppression of Raf-1 kinase activity and MAP kinase signalling by RKIP. Nature, 401, 173-177. doi:10.1038/43686

[20] Yeung, K., Janosch, P., McFerran, B., Rose, D.W., Mischak, H., Sedivy, J. M. and Kolch, W. (2000) Mechanism of suppression of the Raf/MEK/extracellular signalregulated kinase pathway by the Raf kinase inhibitor protein. Molecular Cell Biology, 20, 3079-3085. doi:10.1128/MCB.20.9.3079-3085.2000

[21] Fu, Z., Smith, P.C., Zhang, L., Rubin, M.A., Dunn, R.L., Yao, Z. and Keller, E.T. (2003) Effects of raf kinase inhibitor protein expression on suppression of prostate cancer metastasis. Journal of the National Cancer Institute, 95, 878-889. doi:10.1093/jnci/95.12.878

[22] Schuierer, M.M., Bataille, F., Hagan, S., Kolch, W. and Bosserhoff, A.K. (2004) Reduction in Raf kinase inhibitor protein expression is associated with increased Rasextracellular signal-regulated kinase signaling in melanoma cell lines. Cancer Research, 64, 5186-5192. doi:10.1158/0008-5472.CAN-03-3861

[23] Schuierer, M.M., Bataille, F., Weiss, T., Hellerbrand, C. and Bosserhoff, A.K. (2006) Raf kinase inhibitor protein is downregulated in hepatocellular carcinoma. Oncology Reports, 16, 451-456.

[24] Hagan, S., Al-Mulla, F., Mallon, E., Oien, K., Ferrier, R., Gusterson, B., García, J.J. and Kolch, W. (2005) Reduction of Raf-1 kinase inhibitor protein expression correlates with breast cancer metastasis. Clinical Cancer Research, 11, 7392-7397. doi:10.1158/1078-0432.CCR-05-0283
[25] Al-Mulla, F., Hagan, S., Behbehani, A.I., Bitar, M.S., George, S.S., Going, J.J., García, J.J., Scott, L., Fyfe, N., Murray, G.I. and Kolch, W. (2006) Raf kinase inhibitor protein expression in a survival analysis of colorectal cancer patients. Journal of Clinical Oncology, 24, 56725679. doi:10.1200/JCO.2006.07.5499

[26] Zlobec, I., Baker, K., Minoo, P., Jass, J.R., Terracciano, L. and Lugli, A. (2008) Node-negative colorectal cancer at high risk of distant metastasis identified by combined analysis of lymph node status, vascular invasion, and Raf-1 kinase inhibitor protein exoression. Clinical Cancer Research, 14, 143-148. doi:10.1158/1078-0432.CCR-07-1380

[27] Houben, R., Vetter-Kauczok, C.S., Ortmann, S., Rapp, U.R., Broecker, E.B. and Becker, J.C. (2008) PhosphoERK staining is a poor indicator of the mutational status of BRAF and NRAS in human melanoma. Journal of Investigative Dermatology, 128, 2003-2012. doi:10.1038/jid.2008.30

[28] Nakamura, S., Hirano, I., Okinaka, K., Takemura, T., Yokota, D., Ono, T., Shigeno, K., Shibata, K., Fujisawa, S. and Ohnishi, K. (2010) The FOXM1 transcriptional factor promotes the proliferation of leukemia cells through modulation of cell cycle progression in acute myeloid leukemia. Carcinogenesis, 31, 2012-2021. doi:10.1093/carcin/bgq185

[29] Wellbrock, C., Karasarides, M. and Marais, R. (2004) The RAF proteins take centre stage. Nature Reviews Molecular Cell Biology, 5, 875-885. doi:10.1038/nrm1498

[30] Dhillon, A.S., Hagan, S., Rath, O. and Kolch, W. (2007) MAP kinase signaling pathways in cancer. Oncogene, 26, 3279-3290. doi:10.1038/sj.onc. 1210421

[31] Roberts, P.J. and Der, C.J. (2007) Targeting the Raf-MEKERK mitogen-activated protein kinase cascade for the treatment of cancer. Oncogene, 26, 3291-3310. doi:10.1038/sj.onc. 1210422

[32] Schubbert, S., Shannon, K. and Bollag, G. (2007) Hyperactive Ras in developmental disorders and cancer. $\mathrm{Na}$ ture Reviews Cancer, 7, 295-308. doi:10.1038/nrc2109

[33] Li, H.Z., Gao, Y., Zhao, L.X., Liu, Y.X., Sun, B. C., Yang, J. and Yao, Z. (2009) Effects of Raf kinase inhibitor protein expression on metastasis and progression of human breast cancer. Molecular Cancer Research, 7, 832-840. doi:10.1158/1541-7786.MCR-08-0403

[34] Ye, H., Holterman, A.X., Yoo, K.W., Franks, R.R. and Costa, R.H. (1999) Premature expression of the winged helix transcription factor $\mathrm{HFH}-11 \mathrm{~B}$ in regenerating mouse liver accelerates hepatocyte entry into S-phase. Molecular Cell Biology, 19, 8570-8580.

[35] Laoukili, J., Kooistra, M.R., Bras, A., Kauw, J., Kerkhoven, R.M., Morrison, A., Clevers, H. and Medema, R.H. (2005) FoxM1 is required for execution of the mitotic programme and chromosome stability. Nature Cell Biology, 7, 126-136. doi:10.1038/ncb1217

[36] Wonsey, D.R. and Follettie, M.T. (2005) Loss of the forkhead transcription factor FoxM1 causes centrosome amplification and mitotic catastrophe. Cancer Research, 65, 5181-5189. doi:10.1158/0008-5472.CAN-04-4059

[37] Leung, T.W., Lin, S.S., Tsang, A.C., Tong, C.S., Ching, J.C., Leung, W.Y, Gimlich, R., Wong, G.G. and Yao, K.M. (2001) Over-expression of FoxM1 stimulates cyclin B1 expression. FEBS Letters, 507, 59-66. 
doi:10.1016/S0014-5793(01)02915-5

[38] Wang, X., Kiyokawa, H., Dennewitz, M.B. and Costa, R.H. (2002) The forkhead box mlb transcription factor is essential for hepatocyte DNA replication and mitosis during mouse liver regeneration. Proceedings of the $\mathrm{Na}$ tional Academy Science of the USA, 99, 16881-16886. doi:10.1073/pnas.252570299

[39] Petrovic, V., Costa, R.H., Lau, L.F., Raychaudhuri, P. and Tyner, A.L. (2008) FoxM1 regulates growth factor induced expression of the KIS kinase to promote cell cycle progression. Journal of Biological Chemistry, 104, 453460 .
[40] Teh, M.T., Wong, S.T., Neill, G.W., Ghali, L.R., Philpott, M.P. and Quinn, A.G. (2002) FOXM1 is a downstream target of Gli1 in basal cell carcinomas. Cancer Research, 62, 4773-4780.

[41] Kalinichenko, V.V., Major, M.L., Wang, X., Petrovic, V., Kuechle, J., Yoder, H.M., Dennewitz, M.B., Shin, B., Datta, A., Raychaudhuri, P. and Costa, R.H. (2004) Fox$\mathrm{mlb}$ transcription factor is essential for development of hepatocellular carcinomas and is negatively regulated by the p19ARF tumor suppressor. Genes Development, 18, 830-850. doi:10.1101/gad.1200704 